\title{
Erratum: Evaluation of a new, rapid, simple test for the detection of influenza virus
}

Juan Carlos Hurtado ${ }^{1}$, Mar Mosquera ${ }^{1,2}$, Elisa de Lazzari ${ }^{2}$, Esteban Martínez ${ }^{3}$, Nuria Torner ${ }^{4,5}$, Ricard Isanta ${ }^{1}$, Patricia de Molina ${ }^{1}$, Tomás Pumarola ${ }^{6}$, Jordi Vila ${ }^{1,2}$ and Maria Angeles Marcos ${ }^{1,2^{*}}$

Following publication of [1] it has come to our attention that there was an error in the authorship order and in Jordi Vila's name, which should be Jordi Vila and not Jordi Vila Estape.

We would like to sincerely apologize for the error and any inconvenience caused.

\begin{abstract}
Author details
'Department of Clinical Microbiology, Hospital Clinic, School of Medicine, University of Barcelona, Barcelona, Spain. ${ }^{2}$ Barcelona Centre for International Health Research (CRESIB, Hospital Clinic-Universitat de Barcelona), Barcelona, Spain. ${ }^{3}$ Infectious Diseases Unit, Hospital Clinic-IDIBAPS, University of Barcelona, Barcelona, Spain. ${ }^{4}$ Public Health Agency of Catalonia, Barcelona, Spain. ${ }^{5} \mathrm{C}$ BBER Epidemiology and Public Health (CIBERESP), Madrid, Spain. ${ }^{6}$ Department of Microbiology, Hospital Universitari Vall d'Hebron (HUVH), Universidad Autónoma de Barcelona (UAB), Vall d'Hebron Institut de Recerca (VHIR), Barcelona, Spain.
\end{abstract}

Published online: 22 September 2015

\section{Reference}

1. Hurtado JC, Mosquera MM, de Lazzari E, Martínez E, Torner N, Isanta R, et al. Evaluation of a new, rapid, simple test for the detection of influenza virus. BMC Infect Dis. 2015;15:44.

\footnotetext{
* Correspondence: mmarcos@clinic.ub.es

'Department of Clinical Microbiology, Hospital Clinic, School of Medicine, University of Barcelona, Barcelona, Spain

${ }^{2}$ Barcelona Centre for International Health Research (CRESIB, Hospital

Clinic-Universitat de Barcelona), Barcelona, Spain

Full list of author information is available at the end of the article

\section{Submit your next manuscript to BioMed Central and take full advantage of:}

- Convenient online submission

- Thorough peer review

- No space constraints or color figure charges

- Immediate publication on acceptance

- Inclusion in PubMed, CAS, Scopus and Google Scholar

- Research which is freely available for redistribution

Submit your manuscript at www.biomedcentral.com/submit 